\title{
Amyloidoza AA - przyczyny, diagnostyka, opcje terapeutyczne
}

\author{
AA amyloidosis - causes, diagnostics, therapeutic options
}

\author{
Ewa Więsik-Szewczyk \\ Klinika Chorób Wewnętrznych, Pneumonologii, Alergologii i Immunologii Klinicznej, Wojskowy Instytut Medyczny
}

\begin{abstract}
Streszczenie
Amyloidoza AA jest powiktaniem przewlektych chorób zwiqzanych z aktywacja biatek ostrej fazy. Prekursorem amyloidu jest biatko surowiczego amyloidu A. Nerki sq najczésciej zajętym narzqdem, ale ztogi amyloidu moga być deponowane w każdym narzadzie wewnętrznym. Amyloidoza $A A$ czessto rozwija sie po wielu latach choroby, ale jej wystapienie jest zlym czynnikiem rokowniczym. Nieleczona prowadzi do przewlektej niewydolności nerek. Do pewnego rozpoznania amyloidozy $A A$ konieczne jest potwierdzenie histopatologiczne. Barwienie czerwienia Kongo jest standardowym testem diagnostycznym. Preferowany sposób uzyskania materiatu do badania diagnostycznego to aspiracja tkanki ttuszczowej z powtok jamy brzusznej. Normalizacja parametrów zapalnych, a w konsekwencji brak prekursora deponowanego amyloidu, jest warunkiem koniecznym zahamowania postepu choroby. By kontrolować stan zapalny, konieczne jest intensywne leczenie choroby podstawowej. Wstęne doświadczenia, w matych grupach pacjentów, wskazuja na korzyści wynikajace $z$ zastosowania inhibitorów interleukin 1 oraz 6.

Słowa kluczowe: wtórna amyloidoza, białko surowiczego amyloidu $A$, zespoły autozapalne, interleukina 1, anakinra, tocilizumab
\end{abstract}

Hematologia 2018; 9, 3: 173-180

\begin{abstract}
AA amyloidosis is a complication of chronic diseases associated with the activation of acute phase reactants. The precursor of amyloid is the serum amyloid $A$. The kidneys are the most frequently involved, but amyloid can be deposited in any internal organ. AA amyloidosis often develops after many years of chronic illness, but its occurrence is a poor prognostic factor. Untreated leads to renal failure. For diagnosis of AA amyloidosis, histopathological confirmation is necessary. Staining with Congo red is a standard diagnostic test. Aspiration of abdominal fat is the preferred way to obtain the material for diagnostic testing. Normalization of inflammatory parameters and, as a consequence, the lack of the precursor of the deposited amyloid is a prerequisite for inhibiting the progression of the disease. In order to control inflammation, intensive treatment of the underlying disease is necessary. Initial data, in small groups of patients, indicate the benefits of interleukin 1 and 6 inhibitors.
\end{abstract}

Key words: amyloidosis AA, serum amyloid A, autoinflammatory syndromes, interleukin 1, anakinra, tocilizumab

Hematologia 2018; 9, 3: 173-180

Adres do korespondencji: Ewa Więsik-Szewczyk, Klinika Chorób Wewnętrznych, Pneumonologii, Alergologii i Immunologii Klinicznej, Wojskowy Instytut Medyczny, ul. Szaserów 128, 04-141 Warszawa, tel. 261816 581, faks 261816588 , e-mail: ewa.w.szewczyk@gmail.com 


\section{Wprowadzenie}

Amyloidoza AA (amyloidoza reaktywna, określana dawniej mianem amyloidozy wtórnej) jest odległym powikłaniem przewlekłych chorób zapalnych, rzadziej autoimmunizacyjnych. Może być również konsekwencją przewlekłych zakażeń czy nowotworów, które przebiegają $z$ wytwarzaniem białek ostrej fazy, w tym surowiczego amyloidu A (SAA, serum amyloid $A$ ). Nerki są najczęściej zajętym narządem, ale złogi amyloidu mogą się odkładać w każdym narządzie wewnętrznym. Amyloidoza AA często rozwija się po wielu latach choroby, ale jej wystąpienie jest złym czynnikiem rokowniczym. Nieleczona prowadzi do przewlekłej niewydolności nerek, a w skrajnych przypadkach do niewydolności wielonarządowej.

\section{Patogeneza}

Źródłem amyloidu w amyloidozie AA jest SAA [1]. Jest to apolipoproteina, która podobnie jak białko C-reaktywne (CRP, $C$-reactive protein) należy do ewolucyjnie konserwatywnych białek ostrej fazy [2]. Jest wytwarzana przez hepatocyty stymulowane przez interleukinę 6 (IL-6), czynnik martwicy nowotworów alfa (TNF $\alpha$, tumor necrosis factor alpha) oraz interleukinę 1 (IL-1). Średnie stężenie SAA w populacji osób zdrowych wynosi $3 \mathrm{mg} / \mathrm{l}$, w czasie zapalenia może ono wzrastać do $2000 \mathrm{mg} /$ l. Fizjologiczna rola SAA budzi kontrowersje. Ewolucyjnie jest ono elementem odpowiedzi organizmu na stres czy uraz, zaangażowanym w odzyskanie i ponowną utylizację cholesterolu z uszkodzonych komórek [3]. Surowiczy amyloid A jest aktywnie pochłaniany przez makrofagi deponowane w lizosomach i całkowicie rozkładane. U chorych na amyloidozę AA dochodzi do magazynowania pośrednich produktów degradacji SAA, które zdeponowane w przestrzeni międzykomórkowej wiążą glikozaminoglikany, surowicze białko P (SAP, serum amyloid $P$ ) oraz lipidy, co stabilizuje strukturę amyloidu i utrudnia proteolizę.

\section{Przyczyny i epidemiologia}

Ogólem częstość występowania amyloidozy AA na podstawie badań autopsyjnych w krajach zachodnich waha się od 0,5 do $0,86 \%$ [4]. Teoretycznie amyloidoza AA może być konsekwencją każdego przewlekłego stanu zapalnego. Choroby związane $z$ ryzykiem amyloidozy AA przedstawiono w tabeli 1 . Najczęściej jest kojarzona z przewlekłymi chorobami reumatoidalnymi,

Tabela 1. Choroby związane $z$ występowaniem amyloidozy AA

Table 1. Conditions related to AA amyloidosis occurrence

\begin{tabular}{|c|c|c|}
\hline Grupa & Przykłady & $\begin{array}{c}\text { Szacunkowa częstość wśród } \\
\text { chorych na amyloidozę AA }\end{array}$ \\
\hline Przewlekłe zapalenia stawów i kości & $\begin{array}{l}\text { Reumatoidalne zapalenie stawów } \\
\text { Młodzieńcze idiopatyczne zapalenie stawów } \\
\text { Łuszczycowe zapalenie stawów } \\
\text { Zesztywniające zapalenie stawów kręgosłupa } \\
\text { Zespół SAPHO }\end{array}$ & 7-50\%, odsetek zmniejsza się \\
\hline Monogenowe zespoły autozapalne & $\begin{array}{c}\text { Kriopirynopatie } \\
\text { Zespół TRAPS } \\
\text { Zespół hiper-lgD } \\
\text { Rodzinna gorączka śródziemnomorska }\end{array}$ & Ok. $15 \%$, wzrastający odsetek \\
\hline Poligenowe zespoły autozapalne & $\begin{array}{l}\text { Zespół Schnitzler } \\
\text { Choroba Stilla }\end{array}$ & Opisy kazuistyczne \\
\hline Nieswoiste choroby zapalne jelit & $\begin{array}{l}\text { Choroba Leśniowskiego-Crohna } \\
\text { Wrzodziejące zapalenie jelit }\end{array}$ & Ok. $5 \%$ \\
\hline $\begin{array}{l}\text { Stany zwiększające podatność } \\
\text { na zakażenia }\end{array}$ & $\begin{array}{c}\text { Uzależnienie od dożylnych środków narkotycznych } \\
\text { Rozstrzenia oskrzeli } \\
\text { Pospolity zmienny niedobór odporności } \\
\text { HIV/AIDS }\end{array}$ & Do $17 \%$, odsetek wzrastający \\
\hline Choroby nowotworowe & $\begin{array}{l}\text { Rak płuca } \\
\text { Choroba Castlemana } \\
\text { Rak nerki } \\
\text { Chłoniaki }\end{array}$ & Opisy kazuistyczne \\
\hline
\end{tabular}

SAPHO (synovitis acne pustulosis hyperostosis osteitis) — zapalenie stawów, trądzik, łuszczyca krostkowa, nadmierne kościotworzenie, zapalenia kości; TRAPS — zaburzenie spowodowane mutacją genu rodziny receptorów dla czynnika martwicy nowotworów 1A (TNFRSF1A); IgD — immunoglobulina D; HIV (human immunodeficiency virus) - ludzki wirus nabytego niedoboru odporności; AIDS (acquired immune deficiency syndrome) — zespół nabytego niedoboru odporności 
w tym reumatoidalnym zapaleniem stawów (RZS) i młodzieńczym idiopatycznym zapaleniem stawów (JIA, juvenile idiopathic arthritis). Grupą chorób o wysokim ryzyku wystąpienia amyloidozy AA są monogenowe choroby autozapalne - ultrarzadkie choroby uwarunkowane mutacją pojedynczych genów, z których najczęstsza to rodzinna gorączka śródziemnomorska (FMF, familial mediterranean fever) [5]. W praktyce hematologicznej przyczyną amyloidozy AA może być zespół Schnitzler - zespół autozapalny skojarzony z obecnością białka monoklonalnego. Opisano także przypadki chorób onkohematologicznych powikłanych amyloidozą AA [6-11]. W analizach $z$ dwóch ośrodków amerykańskich przyczyną amyloidozy AA w $22-32 \%$ były zapalenia stawów, w $17 \%-$ choroby zapalne jelit, a w 4-5\% - FMF [12-14]. W badaniach europejskich zidentyfikowano następujące przyczyny amyloidozy: JIA $-7-48 \%$, RZS - 23-51\%, zesztywniające zapalenie stawów kręgosłupa - 0-12\%, monogenowe zespoły autozapalne - 9-11\%, przewlekłe zakażenia 9-12\%, łuszczycowe zapalenie stawów - 4\%, choroba Leśniowskiego-Crohna $-2-5 \%$ [15, 16]. Porównania serii pacjentów $z$ potwierdzonym rozpoznaniem amyloidozy AA opisanych w latach 1956-2005 i po roku 2000 wskazują na zmniejszający się odsetek amyloidozy AA w przebiegu przewlekłych zakażeń i zapaleń stawów. Wzrasta natomiast odsetek pacjentów $z$ amyloidozą AA w przebiegu chorób autozapalnych i nowotworów [13]. W badaniu retrospektywnym obejmującym 25 lat odsetek pacjentów $z$ amyloidozą w przebiegu JIA zmniejszył się z 25\% do poniżej $2 \%$, natomiast wzrósł odsetek przypadków amyloidozy AA w grupie osób uzależnionych od dożylnych środków odurzających (z 1\% do 13\%) [17]. W badaniach autopsyjnych amyloidozę AA stwierdzono u od 1,6\% (Niemcy) do 20\% (Serbia) osób przyjmujących narkotyki dożylnie [18], co wiąże się z przewlekłym zakażeniem tkanek miękkich. Wzrasta również istotnie odsetek chorych, u których nie udaje się wyjaśnić przyczyny przewlekłego stanu zapalnego [19].

Dane o występowaniu amyloidozy AA w Polsce są nieliczne. W pracy opublikowanej w 1968 roku $\mathrm{w}$ grupie dzieci z JIA amyloidozę potwierdzono u 10\% [20]. Filipowicz-Sosnowska i wsp. [21] opisali u polskich dzieci z JIA częstszy przebieg systemowy choroby i cięższy obraz kliniczny amyloidozy AA niż u dzieci amerykańskich pomimo porównywalnych stężeń SAA. W grupie polskich dorosłych pacjentów z RZS, u których przesiewowo wykonano badanie tkanki tłuszczowej, złogi amyloidu zidentyfikowano u 37 spośród 121 badanych [22]. W latach 1998-2015 amyloidoza AA w Polsce była wskazaniem do przeszczepienia nerek u 82 chorych $(0,75 \%)$ [23].

\section{Czynniki ryzyka}

Warunkiem powstania amyloidozy AA jest przewlekły stan zapalny, ale tylko u części chorych Z wysokim stężeniem SAA odkładają się złogi amyloidu. Próbowano zatem zidentyfikować czynniki ryzyka predysponujące do rozwoju amyloidozy AA. W RZS wyższym ryzykiem są obciążeni pacjenci z długim przebiegiem choroby i większym stopniem niepełnosprawności [24, 25]. Ważnym czynnikiem jest długotrwałe opóźnienie rozpoznania i wdrożenie celowanego leczenia [19]. U chorych na FMF istotne są pochodzenie etniczne oraz kraj zamieszkania, co sugeruje znaczenie zarówno czynników genetycznych, jak i środowiskowych. W grupie 2000 chorych na FMF kraj pochodzenia był czynnikiem istotniejszym niż czas trwania choroby lub genotyp MEFV (MEditerranean FeVer) [26]. Przypuszczano również, że mutacje genów o częściowej penetracji, związanych $z$ zespołami gorączek nawrotowych, a wpływające na aktywność TNF $\alpha$ oraz IL-1, tj. TNFRSF1A (TNF receptor superfamily type $1 A$ ), MEFV oraz NLRP3 (NOD-like receptor 3 ), mogą być czynnikiem ryzyka amyloidozy AA u chorych na przewlekłe zapalenie stawów. W badanej grupie u 4 spośród 67 chorych na RZS z amyloidozą AA były obecne warianty $M E F V$ w porównaniu $z$ brakiem takich przypadków wśród pacjentów $z$ RZS bez amyloidozy. Wariant R92Q genu TNFRSF1A stwierdzono u 2 z 61 pacjentów $z$ JIA i amyloidozą oraz $u$ ani jednego pacjenta $z$ grupy kontrolnej [27].

Zidentyfikowano pięć alleli kodujących SAA. W populacji japońskiej chorych na RZS obecność allelu SAA1.1 powodowała efekt ochronny, a homozygotyczność SAA1.3 korelowała $z$ wyższym prawdopodobieństwem amyloidozy [28], krótszym czasem od zachorowania do rozwoju amyloidozy i jej cięższym przebiegiem [29]. Ponadto obecność SAA 1.3 wiązała się krótszym przeżyciem oraz słabszą odpowiedzią na stosowane leczenie [29]. Postulowano zasadność wprowadzenia badania alleli SAA w celu wczesnej, spersonalizowanej kwalifikacji do leczenia biologicznego chorych na RZS [30]. Odmienne wyniki uzyskano w ocenie populacji kaukaskiej, w której allele SAA1.1 sprzyjały wystąpieniu amyloidozy AA u chorych na JIA, FMF oraz chorobę Behçeta [31-33]. Obecnie brakuje markera, który pozwoliłby zidentyfikować chorych $z$ grupy ryzyka, u których dojdzie do powstania amyloidozy AA. 


\section{Objawy kliniczne}

Objawy kliniczne zależą od lokalizacji złogów amyloidu. W chwili rozpoznania amyloidozy AA najczęściej zajętym narządem są nerki. Dominujący objaw to proteinuria lub zaburzenia funkcji nerek. U 97\% pacjentów w chwili rozpoznania proteinuria dobowa wynosi ponad $500 \mathrm{mg}$, a stężenie kreatyniny $1,5 \mathrm{mg} / \mathrm{dl}$ i więcej. Opisano również objawy związane $z$ depozycją $w$ naczyniach lub uszkodzeniem cewek nerkowych [34, 35]. $\mathrm{W}$ amyloidozie $\mathrm{AA}, \mathrm{w}$ porównaniu $\mathrm{z}$ amyloidozą $\mathrm{AL}$ z zajęciem nerek, częstsze są nadciśnienie tętnicze i gorsza funkcja nerek [36]. W grupie 374 chorych mediana dobowej proteinurii wynosiła $3,9 \mathrm{~g}, \mathrm{u} 12 \%$ pacjentów białkomocz przekraczał $10 \mathrm{~g} /$ dobę. U co 10. pacjenta doszło do schyłkowej niewydolności nerek (ESRD, end-stage renal disease) [15].

Kolejnym miejscem odkładania amyloidu jest przewód pokarmowy. Objawy to wymioty, biegunka, pseudoniedrożności, zaburzenia wchłaniania, które w ciężkich przypadkach prowadzą do znacznego wyniszczenia pacjenta. Odkładanie złogów amyloidu w naczyniach krwionośnych przewodu pokarmowego zwiększa ich kruchość i może być przyczyną krwawienia [37].

Badania sekcyjne oraz scyntygrafia za pomocą znakowanego SAP wykazują obecność złogów amyloidu w wątrobie (do $25 \%$ pacjentów), natomiast hepatomegalia dotyczy $10 \%$ chorych [15]. Rzadkością jest żółtaczka lub nieprawidłowa aktywność enzymów wątrobowych. W badaniach scyntygraficznych wykrywa się również złogi amyloidu w śledzionie. Zajęcie śledziony należy podejrzewać, jeśli w rozmazie krwi obwodowej obecne są ciałka Howell-Jolly lub zwiększona jest podatność pacjenta na zakażenia bakteryjne [37].

W przebiegu amyloidozy AA zajęcie serca i kardiomiopatia są rzadkością; dotyczą $1 \%$ pacjentów. Klinicznie obserwuje się postać prawokomorowej niewydolności serca. Jeśli wystąpi, jest bardzo złym czynnikiem rokowniczym [38].

\section{Diagnostyka}

Do pewnego rozpoznania amyloidozy AA konieczne jest potwierdzenie histopatologiczne. Standardowym testem diagnostycznym pozostaje barwienie czerwienią Kongo, które potwierdza obecność złogów amyloidu, ale nie umożliwia różnicowania ich typu. Materiał diagnostyczny można uzyskać z zajętego narządu, najczęściej nerek. Jednak $z$ powodu kruchości naczyń, spowodowanej okołonaczyniową depozycją złogów amyloidu, biopsja nerki może się wiązać ze zwiększonym ryzykiem krwawienia. W praktyce reumatologicznej preferuje się aspirację tkanki tłuszczowej brzucha [39]. Procedura jest bezpieczna i może być wykonana $\mathrm{w}$ trybie ambulatoryjnym. Materiał powinien zostać pobrany z 2-5 miejsc do $10 \mathrm{ml}$ strzykawki przy użyciu igły $18-23$ G. Specyficzność metody sięga 93-100\%, czułość $57-82 \%$, choć może być znacznie niższa we wczesnym etapie choroby $(0-19 \%)$ [40]. Alternatywą dla aspiracji tkanki tłuszczowej jest biopsja gruczołów ślinowych dolnej wargi, równiez wykonywana w trybie ambulatoryjnym, bezpieczna i o wysokiej czułości (83-100\%) [41]. W przeszłości wykonywano również biopsję ze śluzówki odbytu. Pobranie powinno być na tyle głębokie, aby uzyskać próbkę $z$ warstwy podśluzowej. Czułość badania ocenia się na 75-85\%. Metoda ta jest częściej stosowana u dzieci niż u dorosłych.

Kolejnym etapem diagnostycznym powinna być ocena immunohistochemiczna $z$ użyciem przeciwciał anty-AA, przeciwciał przeciwko łańcuchom lekkim lambda i kappa [42-44].

Opracowano również technikę obrazowania amyloidu za pomocą scyntygrafii opartą na wiązaniu w złogach amyloidu SAP. Badanie to pozwala na identyfikację złogów w całym organizmie, a więc także ocenę rozległości zmian [45]. Badanie jest i czułe i specyficzne, umożliwia również porównawczą ocenę zmian w trakcie leczenia. Dostępność metody jest ograniczona i poza pojedynczymi ośrodkami nie jest stosowana w praktyce.

\section{Leczenie i monitorowanie}

W amyloidozie AA wtórnej do zapaleń stawów, chorób autoimmunizacyjnych i autozapalnych niezbędna jest kontrola choroby podstawowej. Remisja lub niska aktywność choroby to jednocześnie normalizacja parametrów zapalnych, a w konsekwencji - brak prekursora deponowanego amyloidu [41]. Ważnym elementem leczenia jest zatem skuteczne leczenie modyfikujące przebieg choroby. Różni się ono zależnie od choroby podstawowej. W RZS ,złotym standardem" pozostaje metotreksat, a w FMF niezbędne jest leczenie kolchicyną [46].

W leczeniu amyloidozy AA, niezależnie od typu choroby podstawowej, trwają badania nad skutecznością leków biologicznych, które hamują cytokiny najistotniejsze $\mathrm{w}$ generowaniu produkcji białek ostrej fazy: inhibitory TNF $\alpha$, IL-1 oraz IL-6. W badaniu obserwacyjnym, w którym zastosowano inhibitory $\mathrm{TNF} \alpha$, w grupie 37 chorych na amyloidozę AA o różnych przyczynach, tylko $14 \%$ pacjentów kontynuowało anty-TNF po 10 
latach obserwacji, $32 \%$ chorych zmarło, u $24 \%$ rozwinęło ESRD, a $22 \%$ chorych ze względu na narastająca proteinurię zmieniło typ stosowanego leku biologicznego. W takcie badania zaobserwowano 10 epizodów ciężkich zakażeń związanych ze stosowanym leczeniem, 4 epizody anafilaksji i 4 przypadki zakrzepicy [47]. Wydaje się, że hamowanie aktywności anty-TNF jest skuteczniejsze, jeśli choroba podstawową jest RZS lub zesztywniające zapalenie stawów kręgosłupa [48]. To skuteczniejsza terapia niż stosowany w przeszłości cyklofosfamid [49].

Inhibitory IL-1 $\mathrm{w}$ porównaniu $\mathrm{z}$ inhibitorami $\mathrm{TNF} \alpha$ są lekami o korzystniejszym profilu bezpieczeństwa. Canakinumab oraz anakinrę stosowano $z$ dobrym efektem $w$ małych grupach pacjentów $z$ amyloidozą AA i FMF, w tym u chorych po przeszczepieniu nerki [50, 51]. Korzyści z zahamowania aktywności IL-1 odnieśli także pacjenci $z$ amyloidozą AA o niewyjaśnionej etiologii [52].

Obiecujące są również wyniki badań dotyczących zahamowania aktywności IL-6. Opisano serie przypadków pacjentów leczonych tocilizumabem (inhibitor IL-6) $z$ amyloidozą AA w przebiegu FMF oraz w przebiegu przewlekłych chorób zapalnych. Wyniki te wymagają potwierdzenia $\mathrm{w}$ większych grupach chorych [53-55].

Od 2017 roku w Polsce, w ramach programu terapeutycznego, refundowane jest leczenie anakinrą pacjentów $\mathrm{z}$ amyloidozą AA w przebiegu chorób autozapalnych [56].

Trwała normalizacja stężenia SAA jest konieczna do zatrzymania progresji choroby i poprawy rokowania pacjenta. Podwyższone stężenie SAA kontrolowane w czasie obserwacji koreluje negatywnie $z$ przebiegiem choroby. U chorych, u których mediana stężenia SAA wynosiła $155 \mathrm{mg} / \mathrm{l}$ i więcej, ryzyko zgonu było wielokrotnie wyższe niż u chorych, u których wartość SAA była mniejsza niż $4 \mathrm{mg} / 1$ (ryzyko względne [RR, relative risk] 17,7; 95-proc. przedział ufności [CI, confidence interval] 8,7-36,0]) [15]. Korzyści wynikające $z$ normalizacji SAA są odroczone w czasie, ale tylko w ten sposób jest możliwa regresja istniejących złogów amyloidu. Najkorzystniejsze narzędzie oceny odpowiedzi pacjenta na leczenie przeciwzapalne to monitorowanie stężenia SAA. Koreluje ono ze stężeniem innych markerów zapalnych, w tym CRP, niemniej są pacjenci, u których przy prawidłowym stężeniu CRP wartość SAA pozostaje podwyższona. Ci pacjenci, mimo prawidłowego stężenia CRP, wymagają intensyfikacji leczenia w celu poprawy rokowania [47, 57].
W prowadzeniu pacjentów $z$ amyloidozą AA ważne jest eliminowanie wszystkich stanów potencjalnie zwiększających stężenie SAA. Z tego wynikają wskazania do profilaktycznych szczepień ochronnych przeciwko pneumokokom i corocznie przeciwko grypie.

\section{Rokowanie}

Czas przeżycia pacjentów $\mathrm{z}$ amyloidozą AA oceniano w nielicznych badaniach. W 1991 roku szacowany średni czas przeżycia wynosił 24 miesiące, a w 2008 roku wydłużył się do 79 miesięcy [58-61]. W grupie 327 pacjentów średni czas przeżycia wynosił 133 miesiące [15]. Starszy wiek pacjenta i ESRD wiązały się $z$ większą śmiertelnością. Rokowanie było korzystniejsze u pacjentów, u których przyczyną amyloidozy były zespoły autozapalne i u których stwierdzono regresję złogów w scyntygrafii $z$ użyciem znakowanego SAP [15]. W grupie 86 chorych na amyloidozę AA nerek średni czas przeżycia od rozpoznania wynosił 79 miesięcy, a czas do ESRD, która rozwinęla się u $40 \%$ chorych - 33 miesiące [58]. Niekorzystne czynniki rokownicze to wyższe stężenie kreatyniny oraz większa proteinuria. Wydaje się, że wraz ze ściślejszą wspólpracą nefrologów i reumatologów, wcześniejszym rozpoznaniem i wprowadzeniem terapii celowanych czas przeżycia pacjentów będzie się wydłużał [58].

\section{Podsumowanie}

Amyloidoza AA jest rzadkim powikłaniem zapalnych chorób przewlekłych. Występuje rzadziej niż amyloidoza $\mathrm{AL}$, ale mogą się $z$ nią zetknąć specjaliści wielu dziedzin $z$ zakresu medycyny wewnętrznej. Najczęstszym objawem klinicznym jest uszkodzenie nerek. Diagnozę stawia się na podstawie badania histopatologicznego potwierdzającego obecność złogów amyloidu. Czułą i bezpieczną metodą uzyskania materiału do oceny histopatologicznej jest aspiracja tkanki tłuszczowej powłok jamy brzusznej. Zatrzymanie postępu choroby umożliwia tylko zahamowanie wytwarzania białek ostrej fazy. Surowiczy amyloid A jest cennym markerem odzwierciedlającym kontrolę stanu zapalnego i jego stężenie powinno być systematycznie kontrolowane u pacjentów $z$ amyloidozą AA. Skuteczną ścieżką terapeutyczną jest zahamowanie IL-1.

\section{Konflikt interesów}

Autorka nie zgłasza konfliktów interesu. 


\section{Piśmiennictwo}

1. Parmelee DC, Titani K, Ericsson LH, et al. Amino acid sequence of amyloid-related apoprotein (apoSAA1) from human high-density lipoprotein. Biochemistry. 1982; 21(14): 3298-3303, doi: 10.1021/bi00257a008, indexed in Pubmed: 7115671.

2. Jayaraman S, Gantz DL, Haupt C, et al. Serum amyloid A forms stable oligomers that disrupt vesicles at lysosomal $\mathrm{pH}$ and contribute to the pathogenesis of reactive amyloidosis. Proc Natl Acad Sci USA. 2017; 114(32): E6507-E6515, doi: 10.1073/ /pnas.1707120114, indexed in Pubmed: 28743750.

3. Kisilevsky R, Manley PN. Acute-phase serum amyloid A: perspectives on its physiological and pathological roles. Amyloid. 2012; 19(1): 5-14, doi: 10.3109/13506129.2011.654294, indexed in Pubmed: 22320226.

4. Real de Asúa D, Costa R, Galván JM, et al. Systemic AA amyloidosis: epidemiology, diagnosis, and management. Clin Epidemiol. 2014; 6: 369-377, doi: 10.2147/CLEP.S39981, indexed in Pubmed: 25378951.

5. Lane T, Loeffler JM, Rowczenio DM, et al. AA amyloidosis complicating the hereditary periodic fever syndromes. Arthritis Rheum. 2013; 65(4): 1116-1121, doi: 10.1002/art.37827, indexed in Pubmed: 23280696.

6. Zhu LC, Sidhu GS, Yee HT, et al. AA-type amyloidosis associated with non-Hodgkin's lymphoma: a case report. Hum Pathol. 2004; 35(8): 1041-1044, doi: 10.1016/j.humpath.2004.05.004, indexed in Pubmed: 15297973.

7. Rowczenio DM, Pathak S, Arostegui JI, et al. Molecular genetic investigation, clinical features, and response to treatment in 21 patients with Schnitzler syndrome. Blood. 2018; 131(9): 974-981, doi: 10.1182/blood-2017-10-810366, indexed in Pubmed: 29284595.

8. Honda A, Kakihana K, Mori J, et al. Gastrointestinal AA amyloidosis following allogeneic hematopoietic stem cell transplant in a patient with chronic myelogenous leukemia. Leuk Lymphoma. 2013; 54(8): 1794-1796, doi: 10.3109/10428194.2012.751531, indexed in Pubmed: 23163702.

9. Tajima S, Ushijima T, Matuya S, et al. AA-type amyloidosis in association with non-Hodgkin's lymphoma following CMV viremia: autopsy case. Pathol Int. 2010; 60(3): 222-227, doi: 10.1111/j.14401827.2009.02505.x, indexed in Pubmed: 20403049.

10. Piskin O, Alacacioglu I, Ozkal S, et al. A patient with diffuse large B-cell non-Hodgkin's lymphoma and AA type amyloidosis. J BUON. 2008; 13(1): 113-116, doi: 10.1002/0471684228. egp00583, indexed in Pubmed: 18404797.

11. Manwani R, Wrench D, Wechalekar A, et al. Successful treatment of systemic AA amyloidosis associated with underlying Hodgkin lymphoma. Br J Haematol. 2018; 182(5): 619, doi: 10.1111/ /bjh.15269, indexed in Pubmed: 29767440.

12. Simms RW, Prout MN, Cohen AS. The epidemiology of AL and AA amyloidosis. Baillieres Clin Rheumatol. 1994; 8(3): 627-634, doi: 10.1016/s0950-3579(05)80119-0, indexed in Pubmed: 7954866.

13. Girnius S, Dember L, Doros G, et al. The changing face of AA amyloidosis: a single center experience. Amyloid. 2011; 18(Suppl 1): 226-228, doi: 10.3109/13506129.2011.574354085, indexed in Pubmed: 21838497.

14. Gillmore JD, Lovat LB, Persey MR, et al. Amyloid load and clinical outcome in AA amyloidosis in relation to circulating concentration of serum amyloid A protein. Lancet. 2001; 358(9275): 24-29, doi: 10.1016/S0140-6736(00)05252-1, indexed in Pubmed: 11454373 .
15. Lachmann HJ, Goodman HJB, Gilbertson JA, et al. Natural history and outcome in systemic AA amyloidosis. N Engl J Med. 2007; 356(23): 2361-2371, doi: 10.1056/NEJMoa070265, indexed in Pubmed: 17554117.

16. Prakash J, Brojen T, Rathore SS, et al. The changing pattern of renal amyloidosis in Indian subcontinent: two decades of experience from a single center. Ren Fail. 2012; 34(10): 1212-1216, doi: 10.3109/0886022X.2012.723514, indexed in Pubmed: 23009273.

17. Lane T, Pinney JH, Gilbertson JA, et al. Changing epidemiology of AA amyloidosis: clinical observations over 25 years at a single national referral centre. Amyloid. 2017; 24(3): 162-166, doi: 10 .1080/13506129.2017.1342235, indexed in Pubmed: 28686088.

18. Harris M, Brathwaite R, Scott J, et al. Drawing attention to a neglected injecting-related harm: a systematic review of AA amyloidosis among people who inject drugs. Addiction. 2018; 113(10): 1790-1801, doi: 10.1111/add.14257, indexed in Pubmed: 29697879.

19. Blank N, Hegenbart U, Lohse P, et al. Familial Mediterranean fever in Germany: clinical presentation and amyloidosis risk. Scand J Rheumatol. 2013; 42(1): 52-58, doi: 10.3109/03009742.2012.71 4796, indexed in Pubmed: 23137073.

20. Roztropowicz-Denisiewicz K, Małdyk E, Wagner T. Amyloidosis in juvenile rheumatic arthritis. Ped Pol. 1968; 43: 3-11.

21. Filipowicz-Sosnowska AM, Roztropowicz-Denisiewicz K, Rosenthal CJ, et al. The amyloidosis of juvenile rheumatoid arthritis - comparative studies in Polish and American children. I. Levels of serum SAA protein. Arthritis Rheum. 1978; 21(6): 699-703, doi: 10.1002/art.1780210615, indexed in Pubmed: 737000.

22. Wiland P, Wojtala R, Goodacre J, et al. The prevalence of subclinical amyloidosis in Polish patients with rheumatoid arthritis. Clin Rheumatol. 2004; 23(3): 193-198, doi: 10.1007/s10067-0030842-y, indexed in Pubmed: 15168143.

23. Ciszek M, Kisiel B, Czerwinski J, et al. Kidney transplant recipients with rheumatic diseases: epidemiological data from the Polish Transplant Registries 1998-2015. Transplant Proc. 2018; 50(6): 1654-1657, doi: 10.1016/j.transproceed.2018.03.122, indexed in Pubmed: 30056876.

24. Gómez-Casanovas E, Sanmartí R, Solé M, et al. The clinical significance of amyloid fat deposits in rheumatoid arthritis: a systematic long-term followup study using abdominal fat aspiration. Arthritis Rheum. 2001; 44(1): 66-72, doi: 10.1002/15290131(200101)44:1<66::AID-ANR10>3.0.CO;2-H, indexed in Pubmed: 11212178.

25. Koivuniemi R, Paimela L, Suomalainen R, et al. Amyloidosis as a cause of death in patients with rheumatoid arthritis. Clin Exp Rheumatol. 2008; 26(3): 408-413, doi: 10.3109/03009742.2010.5 04188, indexed in Pubmed: 18578961.

26. Touitou I, Sarkisian T, Medlej-Hashim M, et al. International Study Group for Phenotype-Genotype Correlation in Familial Mediterranean Fever. Country as the primary risk factor for renal amyloidosis in familial Mediterranean fever. Arthritis Rheum. 2007; 56(5): 1706-1712, doi: 10.1002/art.22507, indexed in Pubmed: 17469185.

27. Aganna E, Hawkins PN, Ozen S, et al. Allelic variants in genes associated with hereditary periodic fever syndromes as susceptibility factors for reactive systemic AA amyloidosis. Genes Immun. 2004; 5(4): 289-293, doi: 10.1038/sj.gene.6364070, indexed in Pubmed: 15071491.

28. Moriguchi M, Terai C, Koseki Y, et al. Influence of genotypes at SAA1 and SAA2 loci on the development and the length of latent period of secondary AA-amyloidosis in patients with rheumatoid arthritis. Hum Genet. 1999; 105(4): 360-366, doi: 10.1007/ /s004399900150, indexed in Pubmed: 10543406. 
29. Nakamura T, Higashi S, Tomoda K, et al. Significance of SAA1.3 allele genotype in Japanese patients with amyloidosis secondary to rheumatoid arthritis. Rheumatology (Oxford). 2006; 45(1): 43-49, doi: 10.1093/rheumatology/kei112, indexed in Pubmed: 16219644.

30. Nakamura T. Clinical strategies for amyloid A amyloidosis secondary to rheumatoid arthritis. Mod Rheumatol. 2008; 18(2): 109-118, doi: 10.1007/s10165-008-0035-2, indexed in Pubmed: 18369528

31. Booth DR, Booth SE, Gillmore JD, et al. SAA1 alleles as risk factors in reactive systemic AA amyloidosis. Amyloid. 1998; 5(4): 262-265, indexed in Pubmed: 10036584.

32. Gershoni-Baruch R, Brik R, Zacks N, et al. The contribution of genotypes at the MEFV and SAA1 loci to amyloidosis and disease severity in patients with familial Mediterranean fever. Arthritis Rheum. 2003; 48(4): 1149-1155, doi: 10.1002/art.10944, indexed in Pubmed: 12687559.

33. Utku U, Dilek M, Akpolat I, et al. SAA1 alpha/alpha alleles in Behçet's disease related amyloidosis. Clin Rheumatol. 2007; 26(6): 927-929, doi: 10.1007/s10067-006-0435-7, indexed in Pubmed: 17039260 .

34. Westermark GT, Sletten K, Westermark P. Massive vascular AA-amyloidosis: a histologically and biochemically distinctive subtype of reactive systemic amyloidosis. Scand J Immunol. 1989; 30(5): 605-613, doi: 10.1111/j.1365-3083.1989.tb02468.x, indexed in Pubmed: 2587936.

35. Hiki Y, Horii A, Kokubo T, et al. A case of rheumatoid arthritis with renal tubular amyloidosis. Nephron. 1994; 68(3): 394-395, doi: 10.1159/000188412, indexed in Pubmed: 7838272.

36. Kuroda T, Tanabe N, Hasegawa E, et al. Significant association between renal function and area of amyloid deposition in kidney biopsy specimens in both AA amyloidosis associated with rheumatoid arthritis and AL amyloidosis. Amyloid. 2017; 24(2): 123-130, doi: 10.1080/13506129.2017.1338565, indexed in Pubmed: 28613962.

37. Systemic consequences of the inflammatory process: amyloidosis, anaemia, atherosclerosis. https://www.eular.org/sysModules/ /sysFiles/ckeditor_4/plugins/doksoft_uploader/userfiles/Module\%20titles\%20list\%202018_Final.pdf (24.09.2018).

38. Ozawa M, Komatsuda A, Ohtani H, et al. Long-term prognosis of AL and AA renal amyloidosis: a Japanese single-center experience. Clin Exp Nephrol. 2017; 21(2): 212-227, doi: 10.1007/ /s10157-016-1271-y, indexed in Pubmed: 27116248.

39. Hazenberg B, Bijzet J, Limburg P, et al. Diagnostic performance of amyloid A protein quantification in fat tissue of patients with clinical AA amyloidosis. Amyloid. 2009; 14(2): 133-140, doi: 10.1080/13506120701260224.

40. van Gameren II, Hazenberg BPC, Bijzet J, et al. Diagnostic accuracy of subcutaneous abdominal fat tissue aspiration for detecting systemic amyloidosis and its utility in clinical practice. Arthritis Rheum. 2006; 54(6): 2015-2021, doi: 10.1002/art.21902, indexed in Pubmed: 16732553.

41. Caporali R, Bonacci E, Epis O, et al. Safety and usefulness of minor salivary gland biopsy: retrospective analysis of 502 procedures performed at a single center. Arthritis Rheum. 2008; 59(5): 714-720, doi: 10.1002/art.23579, indexed in Pubmed: 18438907.

42. Bély M, Apáthy A. Histochemical and immunohistochemical differential diagnosis of amyloidosis - a brief illustrated essay and personal experience with Romhányi's method. Amyloid. 2000; 7(3): 212-217, doi: 10.3109/13506120009146836, indexed in Pubmed: 11019862 .
43. Sipe JD, Benson MD, Buxbaum JN, et al. Amyloid fibril protein nomenclature: 2010 recommendations from the nomenclature committee of the International Society of Amyloidosis. Amyloid. 2010; 17(3-4): 101-104, doi: 10.3109/13506129.2010.526812, indexed in Pubmed: 21039326.

44. Shah PL, Gillmore JD, Copley SJ, et al. The importance of complete screening for amyloid fibril type and systemic disease in patients with amyloidosis in the respiratory tract. Sarcoidosis Vasc Diffuse Lung Dis. 2002; 19(2): 134-142, doi: 10.1136/ /thx.54.5.444, indexed in Pubmed: 12102609.

45. Hawkins PN, Pepys MB. Imaging amyloidosis with radiolabelled SAP. Eur J Nucl Med. 1995; 22(7): 595-599, doi: 10.1007/ /bf01254559, indexed in Pubmed: 7498219.

46. Marinaki S, Skalioti C, Boletis JN. Colchicine in renal diseases: present and future. Curr Pharm Des. 2018; 24(6): 675-683, doi: 10.2174/1381612824666180123101313, indexed in Pubmed: 29359660 .

47. Esatoglu SN, Hatemi G, Ugurlu S, et al. Long-term follow-up of secondary amyloidosis patients treated with tumor necrosis factor inhibitor therapy: A STROBE-compliant observational study. Medicine (Baltimore). 2017; 96(34): e7859, doi: 10.1097/ /MD.0000000000007859, indexed in Pubmed: 28834898.

48. Pamuk ÖN, Kalyoncu U, Aksu K, et al. A multicenter report of biologic agents for the treatment of secondary amyloidosis in Turkish rheumatoid arthritis and ankylosing spondylitis patients. Rheumatol Int. 2016; 36(7): 945-953, doi: 10.1007/s00296-0163500-9, indexed in Pubmed: 27221456.

49. Nakamura T, Higashi SI, Tomoda K, et al. Effectiveness of etanercept vs cyclophosphamide as treatment for patients with amyloid A amyloidosis secondary to rheumatoid arthritis. Rheumatology (Oxford). 2012; 51(11): 2064-2069, doi: 10.1093/rheumatology/ /kes190, indexed in Pubmed: 22879465.

50. Trabulus S, Korkmaz M, Kaya E, et al. Canakinumab treatment in kidney transplant recipients with AA amyloidosis due to familial Mediterranean fever. Clin Transplant. 2018; 32(8): e13345, doi: 10.1111/ctr.13345, indexed in Pubmed: 29981275.

51. Varan Ö, Kucuk H, Babaoglu H, et al. Efficacy and safety of interleukin-1 inhibitors in familial Mediterranean fever patients complicated with amyloidosis. Mod Rheumatol. 2018 [Epub ahead of print]: $1-4$, doi: 10.1080/14397595.2018.1457469, indexed in Pubmed: 29578360.

52. Lane T, Wechalekar AD, Gillmore JD, et al. Safety and efficacy of empirical interleukin-1 inhibition using anakinra in AA amyloidosis of uncertain aetiology. Amyloid. 2017; 24(3): 189-193, doi: 10.1080/13506129.2017.1352503, indexed in Pubmed: 28745926.

53. Ugurlu S, Hacioglu A, Adibnia Y, et al. Tocilizumab in the treatment of twelve cases with aa amyloidosis secondary to familial mediterranean fever. Orphanet J Rare Dis. 2017; 12(1): 105, doi: 10.1186/s13023-017-0642-0, indexed in Pubmed: 28558744.

54. Lane T, Gillmore JD, Wechalekar AD, et al. Therapeutic blockade of interleukin- 6 by tocilizumab in the management of AA amyloidosis and chronic inflammatory disorders: a case series and review of the literature. Clin Exp Rheumatol. 2015; 33(6, Suppl 94): S46-S53, indexed in Pubmed: 26120866.

55. Courties A, Grateau G, Philippe P, et al. Club Rhumatismes Inflammation and the REGATE Registry. AA amyloidosis treated with tocilizumab: case series and updated literature review. Amyloid. 2015; 22(2): 84-92, doi: 10.3109/13506129.2014.1002031, indexed in Pubmed: 25585627. 
56. Ministerstwo Zdrowia - Choroby nieonkologiczne. https:/www. gov.pl/zdrowie/choroby-nieonkologiczne (24.09.2018).

57. Lange U, Boss B, Teichmann J, et al. Serum amyloid A - an indicator of inflammation in ankylosing spondylitis. Rheumatol Int. 2000; 19(4): 119-122, doi: 10.1007/s002960050114, indexed in Pubmed: 10836520.

58. Bergesio F, Ciciani AM, Manganaro M, et al. Immunopathology Group of the Italian Society of Nephrology. Renal involvement in systemic amyloidosis: an Italian collaborative study on survival and renal outcome. Nephrol Dial Transplant. 2008; 23(3): 941-951, doi: 10.1093/ndt/gfm684, indexed in Pubmed: 17951308.
59. Tanaka F, Migita K, Honda S, et al. Clinical outcome and survival of secondary (AA) amyloidosis. Clin Exp Rheumatol. 2003; 21(3): 343-346, indexed in Pubmed: 12846054.

60. Obici L, Perfetti V, Palladini G, et al. Clinical aspects of systemic amyloid diseases. Biochim Biophys Acta. 2005; 1753(1): 11-22, doi: 10.1016/j.bbapap.2005.08.014, indexed in Pubmed: 16198646.

61. Perfetto F, Moggi-Pignone A, Livi R, et al. Systemic amyloidosis: a challenge for the rheumatologist. Nat Rev Rheumatol. 2010; 6(7): 417-429, doi: 10.1038/nrrheum.2010.84, indexed in Pubmed: 20531382 . 